\title{
DAMPAK PANDEMI COVID-19 TERHADAP KESEJAHTERAAN PETANI TEMBAKAU DI KABUPATEN JOMBANG
}

\author{
Dwi Wahyuni ${ }^{1)}$, Diah Dinaloni ${ }^{2)}$ \\ Magister Pendidikan Ekonomi, STKIP PGRI JOMBANG, dwiwahyuni.stkipjb@gmail.com \\ Magister Pendidikan Ekonomi, STKIP PGRI JOMBANG, d14dnloni@yahoo.co.id
}

\begin{abstract}
Abstrack: Tobacco is one of the important crop commodities in Indonesia. The role of tobacco for the community is quite large because its production and marketing activities involve a number of residents to earn income and work. So tobacco farmers are human resources who are the backbone of economic development, especially in the agricultural sector. The phenomenon that was obtained by the researchers during the observation was that during the covid-19 pandemic the price of tobacco decreased and of course this had a direct impact on the welfare of tobacco farmers in Jombang Regency.

This study aims to analiyze and describe the impact of the covid-19 pandemic on the welfare of tobacco farmers in Jombang Regency. This research is a phenomenological qualitative research. The informants of this research are tobacco farmers, both land owners and farm laborers. Data collection techniques were carried out through observation, open interviews and online data searches. To analyze the data from the interviews, the researchers used analytical techniques consisting of data reduction, data exposure, drawing conclusions and verification.

The results showed that the decline in tobacco prices during the covid-19 pandemic was caused by several things, namely: (1) weather factors such as high rainfall intensity make tobacco leaves become damaged and rotten so that the quality becomes bad, this of course affects the selling price to fall; (2) the PPKM policy imposed by the government during the covid-19 pandemic caused cigarette factories to reduce their production activities, so that tobacco demand decreased and affected tobacco prices which also decreased. The falling tobacco prices have an effect on the income earned by tobacco farmers at harvest, so that the declining income of cource has an impact on the welfare of the farmers. The income from tobacco sales is only sufficient to cover production costs (purchase of seeds, fertilizers, farm labor wages) incurred by farmers during the tobacco planting period, while to cover other needs these tobacco farmers have to do side jobs such as trade and goat farming.
\end{abstract}

Keywords: covid-19 pandemic, welfare, tobacco farmers

Abstrak : Tembakau merupakan salah satu komoditas tanaman penting di Indonesia. Peran tembakau bagi masyarakat cukup besar karena aktifitas produksi dan pemasarannya melibatkan sejumlah penduduk untuk mendapatkan penghasilan dan pekerjaan. Jadi petani tembakau merupakan sumber daya manusia yang menjadi tulang punggung pembangunan ekonomi, khususnya disektor pertanian. Fenomena yang didapat oleh peneliti saat melakukan observasi diketahui bahwa pada masa pandemi covid-19 harga tembakau mengalami penurunan dan tentu saja hal tersebut berdampak langsung pada kesejahteraan petani tembakau di Kabupaten Jombang.

Penelitian ini bertujuan untuk menganalisis dan mendeskripsikan dampak pandemi covid19 terhadap kesejahteraan petani tembakau di Kabupaten Jombang. Penelitian ini merupakan penelitian kualitatif fenomenologis. Adapun yang menjadi informan dari penelitian ini yaitu petani tembakau baik pemilik lahan maupun buruh tani. Teknik pengumpulan data dilakukan melalui observasi, wawancara terbuka dan penelusuran data online. Untuk menganalisis data dari hasil wawancara, peneliti menggunakan teknik analisis yang terdiri atas reduksi data, paparan data, penarikan simpulan dan verifikasi.

Hasil penelitian menunjukkan bahwa menurunnya harga temabakau pada masa pandemi covid-19 disebabkan oleh beberapa hal yaitu (1) faktor cuaca seperti intensitas curah hujan yang tinggi membuat daun tembakau menjadi rusak dan busuk sehingga kualitasnya menjadi jelek, hal ini tentu saja mempengaruhi harga jualnya menjadi turun; (2) kebijakan PPKM yang diberlakukan 
oleh pemerintah pada masa pandemi covid-19 menyebabkan pabrik rokok mengurangi aktifitas produksinya, sehingga permintaan tembakau menurun dan berpengaruh terhadap harga tembakau yang mengalami penurunan juga. Harga tembakau yang turun tersebut berpengaruh pada pendapatan yang diperoleh petani tembakau pada saat panen, sehingga pendapatan yang menurun tentu saja berdampak pada kesejahteraan petani tersebut. Pendapatan dari penjualan tembakau hanya cukup untuk menutup biaya produksi (pembelian bibit, pupuk, upah buruh tani) saja yang dikeluarkan oleh petani selama masa tanam tembakau, sedangkan untuk menutupi kebutuhan lain para petani tembakau ini harus melakukan pekerjaan sampingan seperti berdagang dan ternak kambing.

Kata kunci: pandemi covid-19, kesejahteraan, petani tembakau

\section{A. PENDAHULUAN}

Saat ini dunia tengah dihadapkan pada permasalahan dibidang kesehatan yaitu menyebarnya wabah virus covid-19. Salah satu dampak dari penyebaran covid-19 ini yaitu berdampak pada sektor pertanian di Indonesia baik dari sisi perdagangan, harga, serta menurunnya tingkat pendapatan petani. Seperti diketahui bahwa Indonesia merupakan negara agraris, artinya sektor pertanian dalam pembangunan nasional memegang peranan penting yaitu menyediakan bahan pangan bagi seluruh penduduk. Selain tanaman pangan, perkebunan juga memiliki peran penting dalam menunjang pendapatan negara, salah satu tanaman perkebunan yang mempunyai nilai ekonomis yang tinggi adalah tanaman tembakau. Tembakau merupakan salah satu komoditas tanaman penting di Indonesia. Peran tembakau bagi masyarakat cukup besar karena aktifitas produksi dan pemasarannya melibatkan sejumlah penduduk untuk mendapatkan penghasilan dan pekerjaan. Jadi petani tembakau merupakan sumber daya manusia yang menjadi tulang punggung pembangunan ekonomi, khususnya disektor pertanian. Untuk meningkatkan kualitas dan kuantitas produksi tembakau agar dapat memenuhi kebutuhan konsumen, sumber daya manusia sebagai pelaku utama didalam pembudidayaan perlu dioptimalkan.

Salah satu unsur kesejahteraan petani adalah kemampuan daya beli dari pendapatan petani untuk memenuhi kebutuhan pengeluaran rumah tangga petani. Peningkatan kesejahteraan dapat diukur dari peningkatan daya beli pendapatan untuk memenuhi pengeluaran tersebut. Semakin tinggi daya beli pendapatan petani terhadap kebutuhan konsumsi maka semakin tinggi nilai tukar petani dan berarti secara relatif lebih sejahtera. Nilai tukar petani berkaitan dengan kekuatan relatif daya beli komoditas hasil pertanian yang dihasilkan atau dijual petani dengan barang dan jasa yang dibeli maupun dikonsumsi petani.

Desa Gedongombo merupakan salah satu desa yang masuk dalam wilayah Kecamatan Ploso Kabupaten Jombang dan dikenal sebagai daerah penghasil tembakau. Masyarakat di desa ini lebih banyak menanam lahan sawahnya dengan tanaman tembakau. Petani tembakau di desa ini secara turun-temurun telah menjalankan usahatani tembakau dan lebih banyak memberikan kontribusi sumbangan terhadap pendapatan keluarga petani dalam memenuhi kebutuhan dan menjaga kelangsungan hidup mereka dibandingkan dengan kegiatannya dibidang selain pertanian tembakau. Usahatani tembakau dapat memberikan kontribusi yang besar terhadap pendapatn keluarga. Hasil observasi di lapangan yang telah dilakukan peneliti menunjukkan bahwa harga jual tembakau saat ini di masa pandemi covid-19 telah mengalami penurunan. Adanya fenomena penurunan harga jual tembakau tersebut tentu saja akan berdampak pada kesejahteraan petani tembakau itu sendiri.

Dengan melihat fenomena yang dialami oleh petani tembakau di Desa Gedongombo Kecamatan Ploso Kabupaten Jombang menarik bahwa selama masa pandemi covid-19 terjadi perubahan harga jual tembakau dari petani ke tengkulak dan harga jual tembakau ini diketahui cenderung menurun. Fenomena inilah yang menjadi ketertarikan peneliti untuk mengungkap turunnya harga tembakau dimasa pandemi covid-19 yang tentunya akan berdampak terhadap kesejahteraan petani tembakau di Desa Gedongombo Kecamatan Ploso Kabupaten Jombang. Dengan mengacu pada latar belakang yang peneliti uraikan diatas, maka dalam penelitian ini peneliti menentukan topik penelitan dengan judul "Dampak Pandemi Covid-19 Terhadap 
Kesejahteraan Petani Tembakau di Kabupaten Jombang". Adapun tujuan dari penelitian ini yaitu untuk menganalisis dan mendeskripsikan dampak pandemi covid-19 terhadap kesejahteraan petani tembakau di Kabupaten Jombang.

Penetapan harga merupakan salah satu keputusan terpenting dalam pemasaran. Harga merupakan salah satu unsur bauran pemasaran yang mendatangkan pemasukan atau pendapatan bagi perusahaan, sedangkan ketiga unsur lainnya (produk, distribusi, dan promosi) menyebabkan timbulnya biaya (pengeluaran). Disamping itu, harga merupakan unsur bauran pemasaran yang bersifat fleksibel, artinya dapat diubah dengan cepat. Dari sudut pandang pemasaran, harga merupakan satuan moneter atau ukuran lainnya (termasuk barang dan jasa lainnya) yang ditukarkan agar memperoleh hak kepemilikan atau pengguna suatu barang atau jasa. Tingkat harga yang terjadi dipengaruhi oleh beberapa indikator, antara lain.

a. Kondisi perekonomian sangat mempengaruhi tingkat harga yang berlaku. Pada periode resesi misalnya, merupakan suatu periode dimana harga berada pada suatu tingkat yang lebih rendah.

b. Penawaran dan permintaan; permintaan adalah sejumlah barang yang dibeli oleh pembeli pada tingkat harga tertentu. Pada umumnya tingkat harga yang lebih rendah akan mengakibatkan jumlah yang diminta akan semakin besar. Sedangkan penawaran adalah merupakan kebalikan dari permintaan, yaitu suatu jumlah yang ditawarkan oleh penjual pada suatu tingkat harga tertentu. Pada umumnya, harga yang lebih tinggi medorong jumlah yang ditawarkan sebelumnya.

c. Elastisitas permintaan; sebenarnya sifat permintaan pasar ini tidak hanya mempengaruhi penentuan harganya tetapi juga mempengaruhi volume yang dapat dijual. Untuk beberapa jenis barang, harga dan volume penjualan ini berbanding terbalik, artinya jika terjadi kenaikan harga maka penjualan akan menurun dan sebaliknya.

d. Persaingan; harga jual beberapa macam barang sering dipengaruhi oleh keadaan persaingan yang ada. Barang-barang dari hasil pertanian tembakau misalnya, dijual dalam keadaan persaingan murni (pure competition).

e. Biaya; biaya merupakan dasar dalam penentuan harga, sebab suatu tingkat harga yang tidak dapat menutup biaya akan mengakibatkan kerugian, begitupun sebaliknya.

f. Tujuan perusahaan; tujuan-tujuan yang hendak dicapai antara lain : laba maksimum, volume penjualan tertentu, penguasaan pasar, kembalinya modal yang tertanam dalam jangka waktu tertentu.

g. Pengawasan pemerintah; juga merupakan faktor penting dalam penentuan harga. Pengawasan pemerintah tersebut dapat berbentuk seperti penentuan harga maksimum dan minimum, diskriminasi harga, serta praktik-praktik lain yang mendorong atau mencegah usaha-usaha kearah monopoli.

Menurut Undang-undang No.11 Tahun 2009 tentang Kesejahteraan Masyarakat, dikatakan bahwa kesejahteraan masyarakat adalah kondisi terpenuhinya kebutuhan material, spiritual, dan sosial warga negara agar dapat hidup layak dan mampu mengembangkan diri sehingga dapat melaksanakan fungsi sosialnya. Kesejahteraan social dapat didefinisikan sebagai suatu kondisi kehidupan individu dan masyarakat yang sesuai dengan standar kelayakan hidup yang dipersepsi masyarakat. Tingkat kelayakan hidup dipahami secara relatif oleh berbagai kalangan dan latar belakang budaya, mengingat tingkat kelayakan ditentukan oleh persepsi normatif suatu masyarakat atas kondisi sosial, material, dan psikologis tertentu. Kesejahteraan pada intinya mencakup tiga hal yaitu (Damayanti, 2015).

a. Kondisi kehidupan atau keadaan sejahtera, yakni terpenuhinya kebutuhan- kebutuhan jasmaniah, rohaniah, dan sosial.

b. Institusi, arena atau bidang kegiatan yang melibatkan lembaga kesejahteraan sosial dan berbagai profesi kemanusiaan yang menyelenggarakan usaha kesejahteraan sosial dan pelayanan sosial.

c. Aktivitas, yakni suatu kegiatan-kegiatan atau usaha yang terorganisir untuk mencapai sejahtera. 
Indikator kesejahteraan dapat dilihat dari beberapa aspek yaitu sebagai berikut.

1.Penduduk, menjadi salah satu faktor yang paling penting karena dengan kemampuan yang dimiliki mereka dapat mengelola sumber daya alam yang ada sehingga mereka dapat memenuhi kebutuhan hidupnya secara berkelanjutan.

2.Pendidikan, majunya suatu bangsa dapat dilihat dari kondisi tingkat pendidikan masyarakatnya. Di mana semakin tinggi pendidikan maka bangsa tersebut juga semakin maju, sehingga diharapkan tingginya pendidikan tersebut dapat memberikan dampak yang baik terhadap kesejahteraan masyarakat.

3.Kesehatan, salah satu indikator kesejahteraan masyarakat dalam hal kualitas fisik adalah kesehatan dan gizi, di mana hal ini dapat digunakan untuk melihat peningkatan kesehatan berdasarkan ketersediaan saran prasarana kesehatan, jenis pengobatan, dan pertolongan lainnya.

4.Ketenagakerjaan, aspek ini menjadi salah satu aspek terpenting untuk melihat tingkat kesejahteraan masyarakat yang ada, dengan indikator keberhasilan pembangunan ketenagakerjaan di antaranya Tingkat Pengangguran Terbuka (TPT) dan Tingkat Partisipasi Angkatan Kerja (TPAK).

5.Konsumsi dan Pengeluaran Rumah Tangga, aspek ini juga termasuk salah satu aspek yang penting karena semakin tinggi pendapatan maka pengeluaran rumah tangganya akan ikut meningkat. Di mana yang tadinya pengeluaran hanya digunakan untuk makan tetapi ketika pendapatan meningkat maka akan ada juga pengeluaran bukan untuk makanan.

6. Tempat Tinggal dan Lingkungan, kualitas rumah sebagai tempat tinggal umumya dapat menunjukkan tingkat kesejahteraan suatu rumah tangga, di mana kualitas tersebut ditentukan dari fisik rumah tersebut. Fasilitas lainnya dapat mencerminkan kesejahteraan rumah tangga tersebut antaranya luas rumah, sumber air minum yang digunakan, saluran sanitasi, dan lainlain.

7. Sosial, indikator sosial lainnya untuk melihat kesejahteraan suatu masyarakat dapat juga dilihat dari seberapa sering orang tersebut melakukan perjalanan wisata atau menikmati hiburan, cara orang tersebut mendapatkan informasi misalnya mengakses internet, menonton televisi, mendengarkan radio ataupun membaca surat kabar.

\section{B. METODE PENELITIAN}

Penelitian ini pada dasarnya merupakan penelitian yang bertujuan untuk mengungkap semua fenomena yang berkaitan dengan dampak pandemi covid-19 terhadap kesejahteraan petani tembakau di Kabupaten Jombang. Dengan melihat fenomena yang telah diuraikan sebelumnya pada latar belakang, maka pendekatan yang digunakan dalam penelitian ini adalah "kualitatif fenomenologi". Pendekatan "kualitatif fenomenologi" dilakukan dengan mengungkap semua proses etik yang ada dalam suatu fenomena sosial dan mendeskripsikan kejadian proses social apa adanya, dengan menguraikan interpretasi atas suatu pengalaman dan memberikan arti dari pengalaman yang dirasakan oleh orang-orang. Pendekatan "kualitatif fenomenologi" dilakukan dengan mengungkap semua proses etik yang ada dalam suatu fenomena sosial dan mendeskripsikan kejadian proses sosial apa adanya, dengan menguraikan interpretasi atas suatu pengalaman dan memberikan arti dari pengalaman yang dirasakan oleh orang-orang. Tentunya lebih ditekankan pada kondisi alami, kerja lapangan dengan instrument utamanya peneliti itu sendiri dan lebih banyak pengungkapan yang bersifat deskriptif, dimana yang menjadi perhatian adalah fenomena-fenomena yang nampak maupun gejala-gejala yang melatar belakangi suatu keadaan berdasarkan pemahaman subjektif dari peneliti sendiri. Hal tersebut dilakukan dengan tujuan memahami respon akan keberadaan manusia atau masyarakat serta pengalaman yang dipahami dalam berinteraksi. Dalam melakukan penelitian ini, tentunya peneliti harus memperhatikan hal-hal seperti sikap, karakteristik, cara pandang petani tembakau di Desa Gedongombo Kecamatan Ploso Kabupaten Jombang. Hal ini dilakukan oleh peneliti dengan tujuan supaya tidak terjadi kesalahpahaman pada saat melakukan penelitian.

Dalam penelitian ini, peneliti mengambil obyek penelitian pada masyarakat Desa Gedongombo Kecamatan Ploso Kabupaten Jombang karena di desa ini merupakan salah satu 
desa sebagai penghasil tembakau di Kabupaten Jombang dan mayoritas masyarakat bercocoktanam tembakau. Narasumber (infroman) dalam penelitian adalah petani tembakau (pemilik lahan dan buruh tani). Dalam melakukan penelitian ini ada beberapa teknik yang digunakan oleh peneliti untuk mengumpulkan data yaitu observasi, dokumentasi, wawancara yang dilakukan secara terbuka, penelusuran data secara online.

Dalam penelitian kualitatif, keberadaan seorang peneliti untuk hadir dan terlibat langsung di lapangan dalam mengumpulkan berbagai informasi yang dijadikan sebagai bahan penelitian merupakan sebuah keharusan dan mutlak dilakukan. Hal ini dikarenakan seorang peneliti bertindak sebagai instrumen dan sekaligus sebagai pengumpul data. Kedudukan seorang peneliti dalam penelitian kualitatif diasumsikan sebagai perencana, pelaksana pengumpul data, analis, penafsir data, dan pada akhirnya menjadi pelapor hasil penelitian. Oleh karena itu kehadiran seorang peneliti di lokasi penelitian sangatlah penting untuk diperhatikan karena berkaitan erat dengan aktivitas peneliti sendiri di lapangan. Sehingga untuk kepentingan dalam penelitian ini maka peneliti harus berupaya dapat menciptakan hubungan dan komunikasi yang baik serta harmonis dengan subyek yang diteliti. Disamping itu dalam penelitian kualitatif factor kesungguhan, ketekunan, ketelitian, kesabaran dalam mengumpulkan informasi sangatlah dibutuhkan. Kehadiran peneliti sendiri di lapangan dalam konteks penelitian ini dimaksudkan supaya peneliti bisa lebih memahami secara lebih detail hal-hal yang terkait dengan realitas atau fenomena yang terjadi di lapangan terutama fenomena di Desa Gedongombo yang berkaitan dengan kehidupan para petani tembakau di desa tersebut. Oleh karena itu, selama melakukan penelitian ini peneliti harus memperhatikan hal-hal sebagai berikut.

1. Dalam memasuki lapangan, seorang peneliti harus bersikap dan berperilaku luwes karena informan yang dihadapi terdiri dari informan kunci yaitu petani tembakau, tengkulak. Oleh sebab itu peneliti sendiri berupaya untuk menyesuaikan dan mengikuti dengan adatistiadat, budaya, kebiasaan, dan karakteristik penduduk setempat.

2. Peneliti akan memanfaatkan kegiatan pengamatan untuk mengumpulkan data dari wawancara ke petani tembakau di Desa Gedongombo, maupun ke tengkulak dengan memperhatikan situasi dan karakteristik dari responden. Hal ini dilakukan peneliti sebagai upaya dalam membina hubungan baik dengan subyek penelitian. Artinya peneliti berusaha untuk mendekatkan diri kedalam situasi subyek dengan bergaul apa adanya agar subyek lebih terbuka dalam memberikan jawaban atas segala pertanyaan yang diajukan oleh peneliti, sehingga data yang dibutuhkan dapat diperoleh secara alami dan maksimal.

Dalam penelitian ini data yang dikumpulkan oleh peneliti terdiri atas data primer dan data sekunder. Data primer yang digunakan terkait dengan pengalaman usahatani tembakau, harga jual tembakau, permintaan tembakau, persaingan penjualan tembakau, penggunaan tenaga kerja (buruh tani), kontribusi pendapatan usahatani terhadap pendapatan keluarga, tingkat ketahanan pangan rumah tangga, kemampuan daya beli dimasa pandemi covid-19. Data ini tentu saja diperoleh melalui observasi dan wawancara langsung di lapangan dengan menggunakan instrumen/pedoman wawancara yang telah disiapkan. Sedangkan data sekunder diperoleh dengan mengkaji informasi data dari lembaga terkait sebagai acuan untuk mengetahui demografi penduduk desa setempat seperti mata pencaharian, tingkat pendidikan, luas lahan, dan sebagainya yang diperlukan peneliti untuk melihat kesejahteraan petani tembakau di Desa Gedongombo.

Dalam penelitian ini ada tiga tahapan yang peneliti gunakan untuk menganalisis data penelitian yaitu (1) Reduksi Data (data reduction); (2) Paparan Data (data display); (3) Penarikan Simpulan dan Verifikasi (conclusion drawing/verifying). Berikut gambar dari tahapan analisis data penelitian. 


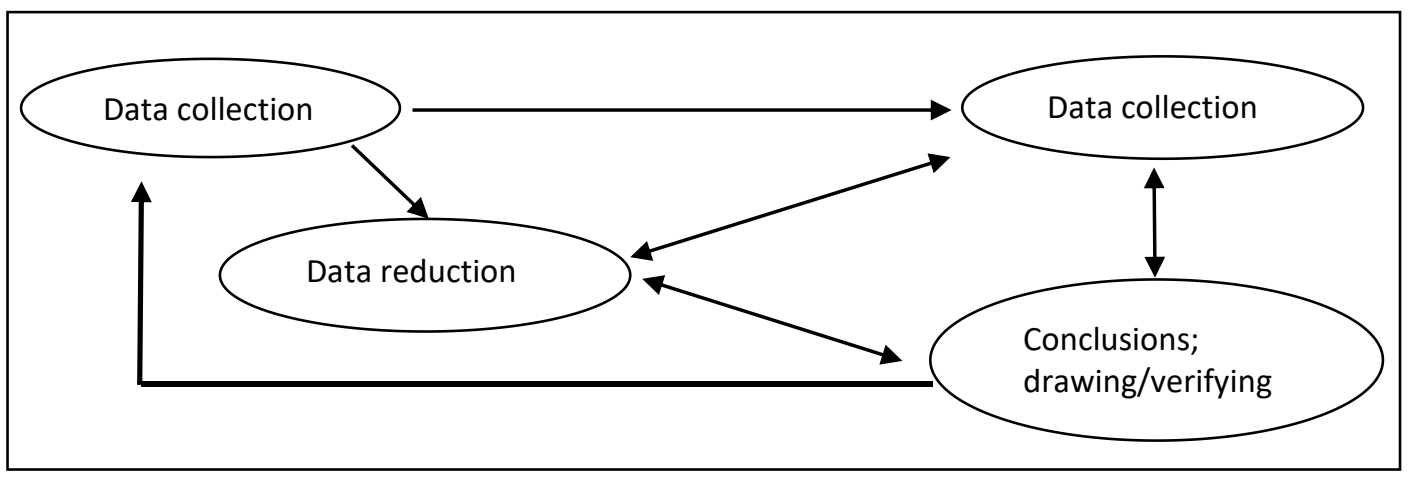

\section{HASIL DAN PEMBAHASAN}

Hasil dari wawancara yang dilakukan oleh peneliti diketahui bahwa kegiatan usaha tani tembakau yang dilakukan oleh masyarakat Desa Gedongombo terdiri dari pengolahan lahan, penanaman, pemupukan, penyiangan, pemberantasan hama dan penyakit, panen, pasca panen (penjemuran, pengirisan tembakau dan pengemasan). Pengolahan lahan dilakukan dengan tujuan untuk menciptakan kondisi lingkungan yang sesuai bagi pertumbuhan dan pembentukan hasil. Pengolahan tanah untuk penanaman tembakau rakyat biasanya dimulai pada awal musim kemarau atau akhir musim penghujan.

Dalam menganalisis data yang diperoleh dari wawancara ke petani tembakau, ada beberapa indikator yang digunakan oleh peneliti untuk mengetahui dampak pandemi covid-19 terhadap kesejaterahaan petani tembakau di Desa Gedongombo Kecamatan Ploso Kabupaten Jombang yaitu luas lahan, pengalaman usahatani tembakau, harga jual tembakau, permintaan tembakau, persaingan penjualan tembakau, penggunaan tenaga kerja (buruh tani), kontribusi pendapatan usahatani terhadap pendapatan keluarga, tingkat ketahanan pangan rumah tangga, kemampuan daya beli.

a) Luas lahan

Luas lahan yang dimiliki petani sangat mempengaruhi besarnya jumlah penerimaan yang akan diterima oleh petani tembakau. Luas lahan petani tembakau yang dilakukan dari tahap pengolahan sampai panen terbagi dalam beberapa kelompok kategori luas lahan yang dapat dilihat pada tabel berikut.

Tabel 1. Luas Lahan Petani Tembakau Desa Gedongombo

\begin{tabular}{|c|l|c|c|}
\hline No & \multicolumn{1}{|c|}{ Luas Lahan (Ha) } & Jumlah (Orang) & Prosentase (\%) \\
\hline 1. & $0,1-0,5$ & 30 & $56,60 \%$ \\
\hline 2. & $0,6-0,15$ & 15 & $28,30 \%$ \\
\hline 3. & $0,16-0,25$ & 5 & $9,43 \%$ \\
\hline 4. & $0,26-0,30$ & 3 & $5,66 \%$ \\
\hline \multicolumn{2}{r|}{ Jumlah } & 53 & $100 \%$ \\
\hline
\end{tabular}

Berdasarkan dari tabel diatas diketahui bahwa prosentase luas lahan terbesar petani tembakau adalah $56,60 \%$ yaitu pada luas lahan $0,1-0,5$ hektar. Sedangkan pada petani tembakau yang memiliki luas lahan terkecil adalah 5,66 \% yaitu pada luas lahan 0,26-0,30 hektar.

b) Pengalaman Usahatani Tembakau

Pengalaman usahatani dapat menggambarkan kemampuan petani dengan banyaknya pengalaman maka petani akan lebih cepat dalam mengambil keputusan terhadap hal yang terjadi jika selama proses usahatani mengalami kendala. Tabel berikut akan menjelaskan berapa lama petani tembakau untuk menjalankan usahanya.

Tabel 2.Pengalaman usahatani Petani Tembakau Desa Gedongombo

\begin{tabular}{|c|l|c|c|}
\hline No & Pengalaman Usahatani & Jumlah (Orang) & Prosentase (\%) \\
\hline 1. & $10-20$ tahun & 20 & $37,73 \%$ \\
\hline 2. & $21-30$ tahun & 14 & $26,41 \%$ \\
\hline
\end{tabular}




\begin{tabular}{|c|l|c|c|}
\hline 3. & $31-40$ tahun & 8 & $15,09 \%$ \\
\hline 4. & $41-50$ tahun & 6 & $11,32 \%$ \\
\hline 5. & $51-60$ tahun & 5 & $9,43 \%$ \\
\hline \multicolumn{2}{|c|}{ Jumlah } & 53 & $100 \%$ \\
\hline
\end{tabular}

Berdasarkan dari tabel diatas diketahui bahwa prosentase pengalaman usahatani terbesar adalah 37,73 \% yaitu petani dengan memiliki pengalaman usahatani 10-20 tahun. Sedangkan prosentase terkecil dari pengalaman usahatani adalah $9,43 \%$ yaitu petani dengan memiliki pengalaman usahatani 51-60 tahun.

c) Harga Jual Tembakau

Penetapan harga dapat diartikan suatu nilai yang ditetapkan oleh para tengkulak tembakau kepada hasil panen para petani tembakau. Dalam kata lain penetapan harga merupakan salah-satunya unsur bauran pemasaran yang mendatangkan pemasukan atau pendapatan bagi masyarakat dan bersifat fleksibel artinya dapat diubah dengan cepat. Berdasarkan hasil wawancara yang dilakukan oleh peneliti, diketahui bahwa adanya penetapan harga tembakau yang dilakukan oleh petani Desa Gedongombo pada massa pandemi covid-19 mengalami penurunan. Hal ini dikarenakan oleh beberapa hal yaitu (1) faktor cuaca dimana intensitas hujan yang tinggi menyebabkan daun tembakau menjadi rusak, busuk sehingga mempengaruhi kualitas tembakau itu sendiri saat diproses menjadi tembakau rajangan maupun tembakau janturan; (2) adanya kebijakan selama masa pandemi covid-19 yaitu penerapan PPKM yang berpengaruh langsung terhadap permintaan tembakau ke petani dari pabrik rokok, dikarenakan pabrik rokok dibatasi untuk tidak melakukan aktifitas produksi. Kedua faktor inilah yang menyebabkan harga jual tembakau turun selama masa pandemi covid-19. Jika sebelumnya harga tembakau sebelum pandemi covid-19 berkisar antara Rp. 35.000,- sampai Rp. 25.000,- perkilogram, sedangkan harga saat pandemi covid-19 berkisar antara Rp. 23.000,- sampai Rp. 18.000,perkilogram.

d) Permintaan Tembakau

Dari hasil wawancara diketahui bahwa adanya kesepakatan penawaran dan permintaan tembakau tergantung pada kebutuhan pabrik dan kualitas dari tembakau itu sendiri, jika tembakau tersebut sudah tua atau cukup untuk dipanen baru para tengkulak bisa menetapkan harga jual kepada petani tembakau. Permintaan pasar terhadap tembakau tidak hanya mempengaruhi penentuan harga tembakau tetapi juga mempengaruhi volume penjualan tembakau. Pabrik pun ikut menentukan kualitas dari tembakau yang akan dijual di pasaran contohnya menyarankan para petani tembakau untuk memakai pupuk yang dianjurkan dari pabrik tersebut dan tembakau juga ada kualitas grade $\mathrm{A}, \mathrm{B}$ dan $\mathrm{C}$ yang akan dikirim ke pihak pabrik. Diketahui pula bahwa selama masa pandemi covid-19 ini permintaan akan tembakau menurun, hal ini dikarenakan kebijakan PPKM dari pemerintah yang membatasi aktifitas pabrik rokok untuk produksi.

e) Persaingan Penjualan Tembakau

Salah satu faktor yang dapat mempengaruhi harga jual tembakau yaitu persaingan harga dari petani tembakau sendiri. Harga yang ditawarkan tengkulak tergantung pada peluang pabrik atau kebutuhan dari pabrik tembakau itu sendiri, jika kebutuhan pabrik rokok banyak maka para tengkulak bisa untuk mengirim tembakau ke pihak pabrik sehingga disinilah terjadinya persaingan harga tembakau. Selama masa pandemi covid-19 ini persaingan penjualan tembakau juga menurun dikarenakan adanya kebijakan pemberlakuan PPKM yang berdampak pula pada aktifitas produksi pabrik rokok.

f) Penggunaan Tenaga Kerja (Buruh Tani)

Dalam berusahatani tembakau, buruh tani sangat dibutuhkan untuk mengerjakan berbagai macam kegiatan yaitu pengolahan lahan, penanaman, pemupukan, penyiangan, pemberantasan hama dan penyakit, panen, pengirisan, penjemuran, penyortiran dan pengemasan. Berikut peneliti tampilkan penggunaan buruh tani yang digunakan selama proses usahatani tembakau. 
Tabel 3. Rata-rata Penggunaan Buruh Tani Per Hektar Dalam 1 Musim Tanam

\begin{tabular}{|c|l|c|}
\hline No & \multicolumn{1}{|c|}{ Jenis Tahapan Pekerjaan } & Penggunaan Buruh Tani (HKO) \\
\hline 1. & Pengolahan lahan & 8,46 \\
\hline 2. & Penanaman & 7,15 \\
\hline 3. & Pemupukan & 4,51 \\
\hline 4. & Penyiangan & 4,38 \\
\hline 5. & Pemberantasan Hama dan Penyakit & 3,92 \\
\hline 6. & Panen & 4,64 \\
\hline 7. & Pengirisan & 3,43 \\
\hline 8. & Penjemuran & 4,30 \\
\hline 9. & Penyortiran & 3,84 \\
\hline 10. & Pengemasan & 4,10 \\
\hline \multicolumn{2}{|c|}{ Total Buruh Tani } & 48,73 \\
\hline
\end{tabular}

Berdasarkan tabel diatas diketahui bahwa rataan kebutuhan buruh tani per hektar dalam 1 musim tanam ( 3 bulan) sebanyak 48,73 HKO. Penggunaan buruh tani (HKO) per hektar dalam 1 musim tanam terbesar adalah pengolahan lahan yaitu 8,46 HKO dan yang terkecil adalah pengirisan yaitu 3,43 HKO.

Besarnya pendapatan rata-rata usahatani tembakau di Desa Gedongombo dapat dilihat pada tabel berikut ini.

Tabel 4. Pendapatan Rata-rata Usahatani Tembakau Desa Gedongombo

\begin{tabular}{|c|l|c|c|}
\hline \multirow{2}{*}{ No } & \multirow{2}{*}{ Uraian } & \multicolumn{2}{|c|}{ Nilai Rupiah } \\
\cline { 3 - 4 } & & Per Petani & Per Hektar \\
\hline 1. & Total Penerimaan & $15.996 .153,84$ & $49.917 .582,41$ \\
\hline 2. & Total Biaya Produksi & $5.795 .370,87$ & $23.824 .281,51$ \\
\hline \multicolumn{2}{|c|}{ Pendapatan Bersih Usahatani } & $10.200 .782,97$ & $26.093 .300,90$ \\
\hline
\end{tabular}

Berdasarkan tabel diatas dapat diketahui bahwa pendapatan usahatani tembakau selama satu musim tanam adalah sebesar Rp. 10.200.782,97/petani atau Rp. 26.093.300,90/Ha di Desa Gedongombo Kecamatan Ploso Kabupaten Jombang.

g) Kontribusi Pendapatan Usahatani Tembakau Terhadap Pendapatan Keluarga

Sumber pendapatan keluarga petani di Desa Gedongombo selain dari usahatani tembakau diperoleh dari non usahatani yaitu berdagang (warung, toko kelontong) dan ternak kambing. Hal ini dapat dilihat dari hasil wawancara kepada petani bahwa mereka membuka toko atau warung serta ada juga yang beternak kambing.

Tabel 5. Pendapatan Petani Non Usahatani Tembakau

\begin{tabular}{|c|l|c|}
\hline No & \multicolumn{1}{|c|}{ Uraian } & Per Petani (Rupiah) \\
\hline 1. & Pendapatan petani dari berdagang per bulan & $1.750 .000,00$ \\
\hline 2. & $\begin{array}{l}\text { Pendapatan petani dari beternak kambing tiap } \\
\text { penjualan }\end{array}$ & $7.250 .000,00$ \\
\hline
\end{tabular}

Berdasarkan tabel diatas diketahui bahwa untuk menutupi kebutuhan rumah tangga, petani tembakau di Desa Gedongombo mengandalkan dari pendapatan lain selain tembakau yang diperoleh yaitu dengan berdagang (warung atau toko kelontong) sebesar Rp. 1.750.000,00 setiap bulan dan menjual hasil ternak kambing dengan pendapatan yang diperoleh sebesar Rp. 7.250.000,00 tiap kali penjualan.

h) Tingkat Ketahanan Pangan Rumah Tangga

Perkembangan tingkat ketahanan pangan di tingkat rumah tangga dapat menunjukkan indikator kesejahteraan petani tembakau. Semakin tinggi tingkat ketahanan pangan rumah tangga (dari hasil produksi sendiri), diasumsikan semakin kuatnya pemenuhan kebutuhan pangan keluarga atau semakin banyak stok persediaan pangan rumah tangga sehingga menjadi indikator semakin sejahtera rumah tangga petani tembakau yang bersangkutan. Hasil wawancara peneliti dengan petani tembakau menunjukkan bahwa meskipun harga jual tembakau turun tetapi para petani tembakau ini masih dapat memenuhi kebutuhan pangan rumah tangganya. 
i) Kemampuan Daya Beli

Daya beli rumah tangga petani tembakau dapat digunakan sebagai indikator kesejahteraan. Secara umum daya beli masyarakat petani tembakau di Desa Gedongombo tergolong relatif baik. Tingkat daya beli petani dengan sumber pendapatan utama dari sektor pertanian merupakan rasio antara total pendapatan rumah tangga dengan total pengeluaran rumah tangga petani yang sudah dikurangi dengan biaya usahatani. Hasil wawancara peneliti dengan petani tembakau menunjukkan bahwa pendapatan yang diperoleh dari hasil menjual tembakau dengan dikurangi biaya usahatani masih memiliki kelebihan yang cukup untuk digunakan membeli kebutuhan pangan rumah tangan.

\section{PENUTUP}

Tembakau merupakan salah satu komoditas tanaman penting di Indonesia. Peran tembakau bagi masyarakat cukup besar karena aktifitas produksi dan pemasarannya melibatkan sejumlah penduduk untuk mendapatkan penghasilan dan pekerjaan. Jadi petani tembakau merupakan sumber daya manusia yang menjadi tulang punggung pembangunan ekonomi, khususnya disektor pertanian.

Kinerja kesejahteraan petani tembakau dalam penelitian ini digambarkan oleh beberapa indikator yaitu luas lahan, pengalaman usatani tembakau, harga jual tembakau, permintaan tembakau, persaingan penjualan tembakau, penggunaan tenaga kerja (buruh tani), kontribusi pendapatan usahatani terhadap pendapatan keluarga, tingkat ketahanan pangan rumah tangga, dan kemampuan daya beli. Dari indikator tersebut menunjukkan hasil bahwa kesejahteraan petani tembakau di Desa Gedongombo relatif tergolong masih baik. Sampai saat ini sektor pertanian terutama usahatani tembakau masih menjadi komoditas utama pencaharian masyarakat di Desa Gedongombo meskipun harga jual tembakau mengalami penurunan tapi masyarakat setempat masih menggarap lahan sawahnya dengan ditanami tembakau. Untuk menutupi kekurangan dalam memenuhi kebutuhan pangan maupun kebutuhan lain (biaya pendidikan anak), para petani tembakau di Desa Gedongombo ini memiliki usaha sampingan yaitu berdagang (warung maupun toko kelontong) dan beternak kambing.

\section{E. DAFTAR PUSTAKA}

Abditama, H. I., dan Damayanti, S. M. (2015). The Influence of Company Performance Toward Stock Price of PT. XL AXATA, TBk from 2008-2014. Journal of Business Management, Vol. 4 No. 4 ISSN: 2409-8447, Hal. 510-521

Adrian, Payne. 2008. The Essence of Service Marketing (Pemasaran Jasa). Jakarta: Salemba Empat

Fajri, Romdhoni. M, Sri Marwanti \& Wiwit Rahayu. Analisis Faktor-fakor yang Mempengaruhi Nilai Tukar Peani Sebagai Indikator Kesejahteraan Petani Padi di Kabupaten Sragen. AGRISTA: Vol. 4 No. 2, Juni 2016. ISSN 2302-1713. https://www.neliti.com/publications/183418/analisis-faktor-faktor-yang-mempengaruhinilai-tukar-petani-sebagai-indikator-ke

Gunawan, Imam. 2016. Metode Penelitian Kualitatif, Teori dan Praktik. PT Bumi Aksara:2016

Hanoatubun, Silpa. Dampak Covid-19 Terhadap Perekonomian Indonesia. Edupscouns Journal, Vol.2 No.1 (2020). https://ummaspul.e-journal.id/Edupsycouns/article/view/423 
Kusnianto, Danang Manumono, Tri Endar. S. 2018. Usaha Tani Tembakau di Desa Kentengsari Kecamatan Candiroto Kabupaten Temanggung. Jurnal MASEPI Vol.3 No.2 Oktober 2018. http://eprints.undip.ac.id

Masruri. 2014. Analisis Efektifitas Program Nasional pemberdayaan masyarakat mandiri perkotaan. Padang: Akademia Permata.

Rachmat, Muchjidin. 2013. Nilai Tukar Petani: Konsep, Pengukuran dan Relevansinya Sebagai Indikator Kesejahteraan Petani. Forum Penelitian Agro Ekonomi (Pusat Sosial Ekonomi dan Kebijakan Pertanian), Vol. 31 No. 2 http://ejurnal.litbang.pertanian.go.id/index.php/fae/article/view/3833

Swasono, Sri-Edi. 2004. Ekspose Ekonomika: Mewaspadai Globalisme dan Pasar Bebas. Yogtakarta: Pustep- UGM

Sugiyono. (2017). Metode Penelitian Kuantitatif, Kualitatif, dan R\&D. Bandung: Alfabeta, CV. https://massugiyantojambi.wordpress.com/2011/04/15/teori-motivasi/

Sadikin, Ikin \& Kasdi. S. 2008. Kinerja Beberapa Indikator Kesejahteraan Petani Padi di Perdesaan Kabupaten Karawang. Balai Pengkajian Teknologi Pertanian https://pse.litbang.pertanian.go.id/ind/pdffiles/MP_Pros_A2_2009.pdf 